\title{
PENGEMBANGAN DESAIN BLANGKON DAN KEMASAN BLANGKON DENGAN METODE QUALITY FUNCTION DEPLOYMENT (QFD)
}

\author{
Dian Janari ${ }^{1}$, Raisha Rahmaditya Khasanah ${ }^{2}$ \\ Jurusan Teknik Industri, Fakultas Teknologi Industri, Universitas Islam Indonesia ${ }^{1,2)}$ \\ Jl. Kaliurang Km. 14,5 Sleman, Yogyakarta 55501 \\ E-Mail :dianjanari@uii.ac.id ${ }^{l}$
}

\begin{abstract}
SME have an important role in improving the economy. There are a number of fields that many SME are involved in, one of which is in the clothing sector. The object of this research is Blangkon production in Beji Village, Yogyakarta. According to Blangkon craftsmen in Beji, less attractive of Blangkon design and packaging have influenced the decreasing of sales number. This study aims to determine the technical requirements and improvements needed for both variables employing the QFD (Quality Function Deployment) method and HOQ (House of Quality). The customer requirements are consisted of exclusive materials, model, durability, convenience, size, color, style, price, and packaging including logo, motif, form, and material. The results showed that exclusive materials, model, packaging motif, and packaging form are required to be improved. Meanwhile, durability, convenience, packaging logo, and packaging material must be maintained and innovated continously. The remaining criterias are maintained. There are 3 design concepts proposed which the design concept $C$ is selected. The second $H O Q$ is applied in order to obtain technical requirements requested.
\end{abstract}

Keywords : Quality Fuction Deployment, House of Quality, Product Design.

\section{PENDAHULUAN}

Industri sandang di Indonesia berkembang pesat, industri besar dan kecil berlomba intuk memberikan inovasi baru. Usaha Kecil dan Menengah (UKM) mempunyai peran yang penting dalam meningatkan perekonomian negara. Pada saat perekonomian negara sedang krisis, kemampuan UKM itu sendiri dalam bertahan di kondisi yang krisis membuktikan bahwa sektor UKM merupakan salah satu sektor usaha yang tangguh. Menurut Berry, et all, (2001) bahwa terdapat tiga alasan mengapa negara berkembang belakangan ini memandang penting keberadaan usaha kecil dan menengah yaitu alasan pertama karena kinerja usaha kecil menangah ini lebih baik dalam hal menghasilkan tenaga kerja yang produktif. Kedua, sebagai bagian dari dinamikanya, usaha kecil dan menengah sering mencapai peningkatan produktifitasnya melalui investasi dan perubahan teknologi. Ketiga, diyakini bahwa usaha kecil dan menengah lebih unggul dalam hal fleksibilitas dari pada usaha besar. Industri kecil dan menengah memiliki pertumbuhan yang pesat di Indonesia yang didominasi dengan industri pangan dan sandang. Dengan inovasi yang diberikan oleh industri kecil dan menengah ini maka muncullah desain, model, dan cara pengolahan produk dengan memanfaatkan bahan dan kreativitas mereka. Namun demikian dalam periode yang sama terdapat UKM yang masih sepi pelanggan. Sukses dibidang industri sandang tidak hanya ditentukan dengan jumlah pelanggan yang menggunakan produk mereka, tetapi juga ditentukan dengan kemampuan meningkatkan pertumbuhan pelanggan.

Kelengkapan busana tradisional jawa yaitu blangkon. Blangkon digunakan sebagai penutup kepala pada busana tradisional jawa. Menurut Soegeng Toekio (1981) blangkon berasal dari kata blangko yang berarti mencetak kosong, adalah suatu nama yang diberikan pada jenis - jenis Iket yang telah dicetak fungsi sosial dari blangkon yaitu menunjukkan martabat atau kedudukan sosial bagi pemiliknya. Kebanyakan orang jawa menjadikan blangkon sebagai simbol atau ciri khas dan konon dulunya dijadikan 
sebagai pembeda antar kaum ningrat. Menurut Soegeng Toekio (1981) masyarakat jawa beranggapan bahwa kepala lelaki memiki arti yang penting, sehingga pelindung kepala lelaki sebagai penutup tubuh yang amat diutamakan, sehingga masyarakat jawa kuno menggunakan blangkon sebagai pakaian keseharian dan dapat dikatakan sebagai pakaian wajib.

Makna estetika dari blangkon tercermin dari bentuk blangkon yang dibuat sedemikian rupa sehingga memancarkan keindahan, makna martabat tercermin dari kegunaan blangkon sebagai alat pembeda antar kaum ningrat Kraton dengan rakyat jelata, dan makna etika tercermin dari kehidupan dan kepribadian orang jawa. Khusus tipe blangkon yang ada di jawa kebanyakan menggunakan tonjolan pada bagian belakangnya yang biasa disebut dengan mondholan. Mondholan ini menandakan bahwa seorang lelaki sering mengikat rambut panjang mereka dibagian belakang kepalanya. Sekarang sudah banyak lelaki yang memotong rambutnya menjadi pendek maka bentuk blangkon di modifikasi dengan membuat mondholan yang dijahit langsung dibagian belakang blangkon. Untuk blangkon gaya Surakarta mondholan-nya trepes sedang untuk mondholan gaya Yogyakarta atau yang banyak dikenal dengan gaya Metaram berbentuk seperti telur atau onde - onde.

Blangkon terbuat dari kain yang disebut dengan kain iket yang memiliki banyak motif batik. Seiring bergantinya zaman banyak budaya dari globalisasi masuk ke tanah Jawa. Hal itu mengakibatkan adanya pergeseran budaya. Jika dulu blangkon merupakan simbol kebanggan pria Jawa dan juga mewakili sifat dan kebiasaan orang jawa itu sendiri, namun bergeser oleh produk-produk barat yang berkembang secara cepat. Pemakaian blangkon dan topi biasa tidaklah berbeda namun yang membedakan adalah cara pandang masyarakat terhadap blangkon.
Pengemasan merupakan suatu cara perlakukan yang diberikan kepada sebuah produk pangan atau sandang, agar produk tersebut menjadi barang yang siap untuk ditransportasikan, didistribusikan, disimpan, dijual, dan dipakai. Sejarah pengemasan di Indonesia tidaklah jauh berbeda perkembangannya dengan kemasan dunia (Sri Julianti, 2014). Bahan kemasan yang umum digunakan yaitu daun, kayu, bambu, gerabah, plastik, kaca, gelas, dan kaleng. Tujuan dari pengemasan itu sendiri yaitu membuat umur simpan produk menjadi lenih panjang, mencegah kerusakan nutrisi/gizi dari produk tersebut, menjaga dan menjamin tingkat kesehatan bahan pangan, dan perlindungan produk itu sendiri.

Menurut Kotler dan Amstrong (2008) kemasan adalah aktivitas merancang dan membungkus suatu produk. Kemasan dengan tata letak yang baik akan menjadi suatu ciri khas dari produknya. Menurut Wirya (1999) tata letak adalah kemampuan merumuskan semua unsur grafis meliputi warna, bentuk, merk, ilustrasi, tipografi menjadi satu kesatuan baru yang disusun ditempatkan pada sebuah halaman kemasan secara utuh dan terpadu. Terdapat 6 hal yang perlu diperhatikan dalam pengembangan tata letak yaitu keseimbangan, titik pandang, kontras, proporsi, alunna pirza (penataan seluruh elemen visual dengan urutan paling logis), dan kesatuan. Kemasan produk yang menarik akan memberikan nilai tambah pada konsumen yang memberdakan beberapa produk yang memiliki bentuk dan mutu yang sama.

Pada penelitian Muchlison Anis dan Hidayati Azizah tahun 2013. Penelitian ini meneliti bagaimana pengaruh industri kreatif blangkon kepada masyarakat dari segi ekonomi dengan mengacu kepada 4 pilar dalam penentuan industry kreatif yaitu ketenagakerjaan, pendapatan, jumlah produksi, dan investasi atau modal awal. 
Hasil yang didapat dari pengukuran produktifitas adalah seluruh aspek meningkat dengan nilai total pada tahun 2014 sebesar 1,655 dan mengalami peningkatan pada tahun 2015 sebesar 2,308. Artinya efektifitas pencapaian tingkat kualitas terhadap efisiensi penggunaan sumber daya mengalami peningkatan. Penelitian Albertus Agastya tahun tahun 2015, penelitian yang berjudul Pengaruh Desain Produk Terhadap Keputusan Pembelian Produk Sepatu Futsal Specs di Kota Bandung. Hasil yang didapat dari perhitungan koefisien determinasi, adalah besarnya pengaruh desain produk sebesar $60,2 \%$ sedangkan sisanya 39,9 dipengaruhi variabel diluar variabel penelitian. Kesimpulan penelitian adalah desain produk mempunyai pengaruh positif dan signifikan terhadap keputusan pembelian.

Penelitian selanjutnya oleh Ida Bagus Suryaningrat dan Wimbi Ren tahun 2015 yaitu berjudul Peningkatan Kualitas Produk Tradisional Prol Tape dengan Metode Quality Fuction Deployment (QFD). Hasil penelitian produk tradisional prol tape adalah ditemukan empat atribut kebutuhan konsumen yaitu rasa, warna aroma, dan tekstur. Terdapat lima tanggapan teknis dari produsen yang memiliki hubungan erat dengan kualitas produk. Dibandingkan yang lain ternyata merek Wika dapat mencapai target yang artinya Wika memiliki kondisi yang lebih baik untuk menjawab kebutuhan konsumen dengan menggunakan teknik tanggapan. Dari latar belakang yang sudah dikemukakan diatas perlu dilakukan penelitian dengan judul merancang usulan perbaikan desain blangkon dan juga kemasan dari produk blangkon untuk menemukan faktor prioritas oleh pelanggan dalam desain dan kemasan blangkon berdasarkan tingkat kepuasan pelanggan dengan Quality Function Deployment.

\section{METODE PENELITIAN}

\subsection{Obyek Penelitian}

Obyek dari penelitian ini adalah produk blangkon yang diproduksi dan dipasarkan dari satu Sentra di Dusun Beji yang terdiri dari 17 UKM pengrajin blangkon.

\subsection{Pengumpulan Data}

Penelitian ini terdapat beberapa metode pengumpulan data yang digunakan yaitu sebagai berikut: (a) Studi Literatur, yaitu pengumpulan teori - teori yang dapat digunakan dalam mendukung pemecahan permasalahan dalam penelitian ini. Metode pengumpulan ini dilakukan dengan meninjau beberapa referensi seperti literatur, buku, laporan - laporan ilmiah dan juga tulisan tulisan ilmiah yang dapat mendukung terbentuknya landasan teori.

Dalam hal ini literatur yang digunakan yaitu yang berhubungan dengan kepuasan konsumen terhadap produk tas, teori tentang Quality Function Dimention dan teori - teori lain yang mendukung, (b) Penelitian Lapangan, yaitu penelitian secara langsung dilapangan yaitu Sentra Blangkon Dusun Beji dan lingkungan itu sendiri baik dengan observasi, wawancara, ataupun dokumentasi ke tempat yang telah dilakukan. Data tersebut diperoleh dengan :

(1) Wawancara, yaitu dilakukan dengan melakukan tanya jawab langsung dengan pemilik usaha ataupun karyawan yang bekerja.

(2) Observasi, yaitu melakukan pencatatan dan pengamatan secara langsung di Sentra Blangkon Dusun Beji.

(3) Penyebaran Kuesioner, kuesioner itu sendiri adalah daftar pertanyaan mengenai produk yang dijual oleh Sentra Blangkon Dusun Beji dan diberikan kepada responden untuk medapatkan informasi tentang penilaian atribut produk yang dibutuhkan dan diinginkan yang mencakup tingkat kepentingan dan harapan yang diberikan oleh Sentra Blangkon Dusun Beji kepada konsumen. 


\subsection{Pengolahan Data}

Menurut Sugiyono (2004) kuesioner merupakan teknik pengumpulan data yang dilakukan dengan membuat daftar pertanyaan atau pernyataan tertulis, baik tertutup maupun terbuka, yang kemudian akan disebarkan kepada responden, jawaban dari responden tersebut yang nantinya akan menjadi data. Teknik pengumpulan data menggunakan kuesioner ini tepat dilakukan untuk mengumpulkan data jika jumlah respondennya banyak kemudian responden juga memiliki kemampuan baca dan tulis, dan hasil yang mendasar adalah bahwa teknik kuesioner dapat digunakan jika peneliti tahu dengan pasti variabel apa yang akan diukur dan tahu apa yang diharapkan oleh responden. Untuk menetapkan berapa jumlah sampel (n) yang dibutuhkan dalam penelitian, maka diputuskan terlebih dahulu berapa tingkat kepercayaan, derajat ketelitian, dan kesalahan sampel yang dikehendaki (sampling error). Pada penelitian ini penulis menggunakan tingkat kepercayaan sebesar 90\%, dengan derajat ketelitian $(\alpha)$ 10\%. Jumlah sampel untuk responden ditentukan dengan menggunakan rumus (Eriyanto, 2007).

Pada penelitian ini kuesioner akan diberikan kepada responden yang telah ditetukan sebelumnya. Terdapat 4 kuesioner yang diberikan,yaitu; (1) Kuesioner pertama merupakan kuesioner terbuka yang menanyakan tentang desain blangkon dan kemasannya yang diinginkan menurut konumen; (2) Kuesioner kedua merupakan kuesioner untuk menentukan tingkat kepentingan terhadap desain produk blangkon lama dan kemasan yang akan di desain sebagai masukan untuk pengembangan terhadap produk blangkon dan kemasan yang baru, dengan skala penilaian; (a) Nilai 1, bila pernyataan tersebut sangat tidak penting; (b) Nilai 2, bila pernyataan tersebut tidak penting; (c) Nilai 3, bila pernyataan tersebut cukup (d) Nilai 4, bila pernyataan tersebut penting, dan; (e) Nilai 5, bila pernyataan tersebut sangat penting; (3) Kuesioner ketiga merupakan pemilihan konsep desain yang terdiri dari tiga desain terpilih yang sudah dilakukan proses seleksi konsep oleh expert. Hasil dari rekapitulasi kuesioner tiga ini yaitu satu desain terpilih menurut responden yang nantinya akan dilakukan penilaian kepentingan; (5) Kuesioner empat merupakan kuesioner tingkat kepentingan dan kepuasan responden, yang berisi nilai tingkat kepentingan responden terhadap desain blangkon lama dan kemasannya sebagai masukan untuk pengembangan desain berikutnya, dengan skala penilaian: (a) Nilai 1, bila pernyataan tersebut sangat tidak penting; (b) Nilai 2, bila pernyataan tersebut tidak penting; (c) Nilai 3, bila pernyataan tersebut cukup; (d) Nilai 4, bila pernyataan tersebut penting, dan Nilai 5, bila pernyataan tersebut sangat penting.

Sedangkan untuk kuesioner kepuasan responden berisi tentang kepuasan responden terhadap produk blangkon lama dan kemasannya, responden hanya dapat menilai yang paling penting dari pertanyaan yang diajukan, dengan skala penilaian: (a) Nilai 1, bila pernyataan tersebut sangat tidak memuaskan; (b) Nilai 2, bila pernyataan tersebut tidak memuaskan; (c) Nilai 3, bila pernyataan tersebut cukup memuaskan; (d) Nilai 4, bila pernyataan tersebut memuaskan, dan Nilai 5, bila pernyataan tersebut sangat memuaskan.

\subsection{Analisa Data}

Validitas adalah suatu indeks yang menunjukkan bahwa alat ukur tersebut benar-benar mengukur yang hendak di ukur. Menurut Wulansari (2007) validitas skala adalah sejauh mana skala tersebut menghasilkan data yang akurat dan cermat sesuai dengan fungsi ukurnya. Berikut adalah langkah-lagkah yang dilakukan untuk analisis vaiditas : (a) Menentukan Hepotesis, (b) Menentukan R-tabel, (c) Mencari nilai R hitung, (d) Membandingkan besar nilai $\mathrm{R}$ table dengan $\mathrm{R}$ hitung. Reabilitas adalah nilai yang menenjukkan apakah suatu alat ukur sudah konsisten atau belum di dalam pengukuran dapat dikatakan data dipercaya atau belum diandalkan (Singarimbun, 1989) Berikut adalah cara dalam melakukan uji 
reliabilitas: (a) Menentukan Hepotesis; (b) Menentukan Ttabel; (c) Menentukan Nilai Ralpha; (d) Pengolahan dengan menggunakan SPSS 16; (e) Pengambilan Keputusan.

Dalam penggunaan metode QFD salah satu prosesnya yaitu melengkapi HOQ (House Of Quality). Tahap pembentukan diagram HOQ (House Of Quality) diawali dengan menerjemahkan voice of custumer yang didapat dari pengumpulan data kuesioner 1 kedalam langkah - langkah sebagai berikut: (a) Melakukan identifikasi mengenai kebutuhan dan keinginan konsunmen terhadap produk blangkon dan kemasan blangkon, lalu pengelompokan keinginan konsumen menjadi karakteristik konsumen.

Seluruh data diuraikan dibagian kiri rumah kualitas; (b) Mengidentifikasikan tingkat kepentingan konsumen untuk masing-masing karakteristik konsumen dan memasukkan nilai-nilai yang didapat kedalam kolom tingkat kepentingan (importance) pada rumah kualitas; (c) Menerjemahkan seluruh kebutuhan dan keinginan konsumen (what's) kedalam karakteristik desain (hows), dimana pada tahap ini menunjukkan bagaimana tempat produksi melakukan tahap desain untuk memenuhi kebutuhan dan keinginan konsumen.

Seluruh data yang didapat diuraikan dan dicatat pada bagian atas dari rumah kualitas; (d) Menentukan hubungan yang terjadi antar karakteristik konsumen dengan karakteristik desain yang dapat dibedakan menjadi 3 katagori hubungan yaitu kuat, sedang, dan lemah. Hubungan ini digambarkan pada bagian tengah rumah kualitas; (e) Menentukan target sentra blangkon Dusun Beji terhadap masing-masing karakteristik desain yang ada, yang nantinya akan diusahakan pencapaiannya demi memenuhi kebutuhan dan keinginan konsumen.

Nilai - nilai tersebut dimasukkan kedalam kolom target yang terletak dibawah rumah kualitas; (f) Membentuk matrix korelasi yang menunjukkan hubungan antar masing-masing karakteristik desain; (g)
Desain produk lama dibandingkan dengan desain produk yang baru berdasarkan karakteristik konsumen yang ada. Sehingga dapat diketahui kekurangan desain yang sudah diperbarui. Informasi ini didapat langsung dari konsumen yang sudah mengenal baik dengan produk yang bersangkutan.

Data ini diletakkan pada bagian kanan rumah kualitas; (h) Desain produk lama dan baru juga dibandingkan berdasarkan karakteristik desain yang didapat pada tahap awal, namun pada tahap ini informasi didapat dari proses wawancara dengan pihak yang bersangkutan. Data ini nantinya akan diletakkan di bagian bawah rumah kualitas; (i) Dengan menggunakan nilai - nilai yang berupa angka pada matrix hubungan keinginan konsumen dan karakteritik desain maka seluruh penilaian dapat disusun berdasarkan kepentingan relatif dari setiap kebutuhan dan keinginan konsumen. Pengurutan item - item ini akan menunjukkan item mana yang membutuhkan perhatian lebih; (j) Tahap Part Deployment, berdasarkan HOQ maka dapat ditentukan faktor teknik yang memungkinkan untuk diperbaiki, yaitu: desain blangkon dan kemasan seperti apa yang paling diinginkan oleh konsumen.

Tahap perencanaan proses, tahapan analisis ini diawali dengan pembuatan peta proses pembuatan blangkon dan kemasannya, dari peta proses tersebut kemudian dihubungkan dengan part kritis yang dihasilkan dari matrix sebelumnya; (k) Tahap perencanaan produksi, tahap ini merupakan tahap terakhir untuk mengetahui tindakan apa yang perlu dilakukan untuk memperbaiki performa rancangan produk blangkon dan kemasannya; (1) Membuat desain perbaikan produk blangkon dan kemasannya berdasarkan hasil rancangan QFD; (m) Mengimplementasikan rancangan perbaikan blangkon dan kemasannya.

\subsection{Tahapan Penelitian}

Tahapan penelitian dijelaskan sebagai berikut: (1) Tahap awal yang dilakukan yaitu merumuskan masalah yang ada pada obyek 
sentra blangkon Dusun Beji, khususnya dalam hal desain produk. Identifikasi masalah dilakukan dengan melakukan pengamatan langsung di tempat penelitian dan dari penelitian terdahulu.

Identifikasi yang sudah didapat selanjutnya akan menjadi rumusan masalah yang akan diteliti; (2) Kajian pustaka yang dilakukan yaitu studi penelitian terdahulu yang berkaitan dengan masalah yang diteliti, teori - teori mengenai desain produk dan metode - metode yang akan digunakan; (3) Pada tahap ini peneliti akan menentukan tujuan dari penelitian yang akan dilakukan dan membahas masalah dan identifikasi masalah yang sudah didapat; (4) Pada tahap ini dilakukan penyusunan kuesioner yaitu didapat 4 kuesioner yang akan dilakukan. Kuesioner 1 untuk mengetahui atribut apa saja yang dibutuhkan oleh pelanggan (voice of customer), kuesioner 2 untuk mengetahui tingkat kepentingan dari setiap atribut menurut pelanggan (important rating), kuesioner 3 untuk mengetahui produk blangkon dan kemasan mana yang terpilih menurut pelanggan, dan kuesioner 4 untuk membandingkan produk dengan desain baru dengan produk yang sudah ada; (5) Pada tahap ini dilakukan uji validitas yaitu untuk mengetahui apakah butir kuesioner sudah dapat dikatan valid atau belum; (6)Pada tahap dilakukan uji reliabilitas yaitu untuk mengetahui apakah butir kuesioner yang diberikan kepada responden dapat dikatakan reliabel atau belum; (7) Pada tahap ini dilakukan pembahasan dengan metode QFD dan menyusun HOQ rumah pertama dan rumah kedua dari data yang sudah didapat. Serta merancang desain akhir; (8) Pada tahap ini dimulai pembuatan prototype blangkon dan kemasan blangkon dengan menggunakan kain mori untuk produk blangkon dan kertas karton untuk kemasan blangkon; (9) Akhir dari penelitian ini yaitu menentukan kesimpulan dari penelitian yang sudah dilakukan serta memberikan saran untuk penelitian selanjutnya dan untuk tempat penelitian sesuai dengan hasil yang sudah didapat.

\section{HASIL PENELITIAN DAN PEMBAHASAN}

\subsection{Desain Blangkon dan Kemasan Blangkon}

Spesifikasi teknis desain blangkon adalah sebagai berikut : (1) Bahan Blangkon menggunakan kain katun jepang; (2) Warna blangkon coklat, dengan motif berwarna coklat muda; (3) ukuran blangkon 53; (4) Blangkon Mempunyai keunikan tulisan jawa berwarna emas pada bagian samping kanan dan kiri yang kalau ditempat gelap dapat menyala (glow in the dark); (5) Tahan lebih dari 1 tahun dan dapat dilipat.

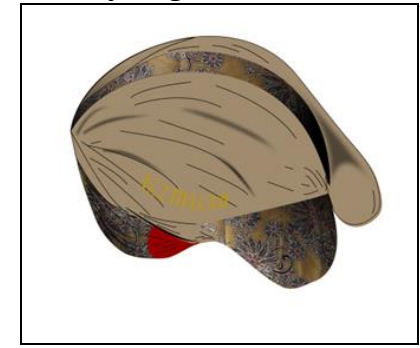

Gambar 1. Desain Blangkon

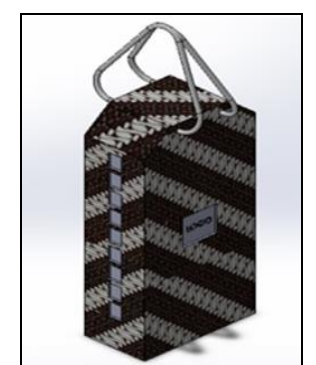

Gambar 2. Kemasan Blangkon. 
Spesifikasi teknis desain kemasan blangkon adalah sebagai berikut : (1) Bahan kemasan terbuat dari karton dengan tebal $1 \mathrm{~mm}$ dengan berat 30 gram; (2) Kemasan berbentuk kotak persegi panjang, cara membuka kotak dengan membuka pada bagian atas, mudah dibawa karena dilengkapi dengan tali; (3) Kemasan bermotif batik jogja berwarna coklat putih ; (4) Pada bagian depan kemasan terdapat logo yang juga tercantum contact person dan alamat pengrajin blangkon; (5) Pada bagian samping terdapat size chart dari blangkon itu sendiri.

\subsection{Hasil Data}

Pengumpulan data melalui kuesioner sebanyak 72 responden diwilayah Yogyakarta yang sudah pernah melihat maupun memegang blangkon. Pada penelitian ini terdapat 3 kuesioner yang memiliki perbedaan masing-masing. Skala yang digunakan pada penelitian ini yaitu skala likert dengan lima skala. Hasil voice of customer (VOC) terdapat pada HOQ.

\subsection{Uji Validitas dan Uji Reliabilitas}

Uji validitas blangkon dan kemasan blangkon yang terbesar adalah bahan blangkon dan kenyamanan kemasan sebesar 0.001 dengan 2 tailed. Uji reliabilitas blangkon pada item 8 sebesar 0.556 dan kemasan blangkon pada item 7 sebesar 0.447 .

\subsection{Importance Rating}

Importance Rating digunakan untuk usaha prioritas dan membuat keputusan trade-off (untuk mengetahui nilai kepentingan kebutuhan konsumen dengan skala relatif atau dengan menggunakan angka yang lebih tinggi untuk mengidentifikasikan tingkat kepentingan menurut konsumen.

\subsection{Menentukan Target}

Target dari perancangan produk ini adalah mendapatkan rancangan blangkon dan kemasan blangkon yang sesuai dengan konsumen inginkan dan butuhkan agar dapat memenuhi semua permintaan keinginan dan kebutuhan konsumen.

\subsection{Matriks Perencanaan Produk (House of Quality)}

Menurut Widodo (2005) konsumen adalah target dan sumber inspirasi pengembangan produk. Pada matriks perencanaan produk ini menjelaskan tentang rumah kualitas (HOQ) iterasi I yang mengkombinasikan dengan voice of customer (kebutuhan pelanggan) dengan karakteristik teknis yang dibuat oleh tim pengembang untuk memenuhi kebutuhan pelanggan.

\subsection{Pembahasan}

A. Berdasarkan pengumpulan data dan perhitungan data, untuk produk blangkon diperoleh hasil bahwa atribut bahan eksklusif memiliki nilai CCE sebesar 4,28 untuk produk blangkonbaru (produk A) dan 3,42 untuk produk blangkon yang sudah ada (produk B). Atribut size blangkon memiliki nilai CCE sebesar 3,93 untuk produk $A$ dan 3,63 untuk produk B. Atribut warna blangkon memiliki nilai CCE sebesar 4,06 untuk produk A dan 3,50 untuk produk B. Atribut awet memiliki nilai CCE sebesar 4,28 untuk produk A dan 3,04 untuk produk. 
B. Atribut kenyamanan blangkon memiliki nilai CCE sebesar 4,24 untuk produk A dan 3,26 untuk produk B. Atribut motif blangkon memiliki nilai CCE sebesar 4,21 untuk produk A dan 3,5 untuk produk B. Atribut harga memiliki nilai CCE sebesar 3,67 untuk produk A dan 3,29 untuk produk B. Atribut blangkon memiliki nilai CCE sebesar 4,03 untuk produk A dan 3,29 untuk produk B. 8 atribut pada produk A sudah memiliki nilai CCE lebih besar dari produk B.

C. Analisis direction improvement dari karakteristik teknis. Tanda panah keatas pada karakteristik teknis nomor 1,5,6,8 dan 10 pada House Of Quality produk blangkon dan pada karakteristik teknis nomor 3,4,5,7, dan 8 pada House Of Quality produk kemasan blangkon memiliki arti bahwa semakin ditingkatkan maka akan semakin baik tidak terbatas. Direction improvement ditentukan oleh pihak pengembang atau peneliti. Analisis perhitungan improvement ratio dan bobot baris.

Tahapan ini merupakan langkah untuk menentukan hasil akhir dari jumlah bobot baris pada perhitungan HOQ. Nilai improvement ratiodiperoleh dari pembagian nilai goal dengan nilai CCE. Nilai improvement ratio pada produk blangkon untuk atribut bahan eksklusif sebesar 1,005, untuk size blangkon sebesar 1,043, untuk warna blangkon sebesar 1,011, untuk awet sebesar 1,005, untuk kenyamanan blangkon sebesar 1,039, untuk motif blangkon sebesar 1,022, untuk harga sebesar 1,102, dan untuk model blangkon sebesar 1,043.
Sedangkan untuk produk kemasan blangkon pada atribut motif kemasan sebesar 1,046, warna kemasan sebesar 1,032 , kenyamanan penggunaan kemasan sebesar 1,043, logo sebesar 1,047, informasi pada kemasan sebesar 1,036, bentuk kemasan sebesar 1,051, dan bahan kemasan sebesar 1,039. Setelah menghitung nilai improvement ratio kemudian dapat dilakukan perhitungan bobot baris. Bobot baris diperoleh dari perkalian antara nilai improvement ratio, sales point, dan improvement rating. Bobot baris untuk produk blangkon atribut bahan eksklusif sebesar 4,668, untuk size blangkon sebesar 4,433, untuk warna blangkon sebesar 4,216, untuk awet sebesar 5,512, untuk kenyamanan blangkon sebesar 5,746, untuk motif blangkon sebesar 4,261, untuk harga sebesar 4,463, dan untuk model blangkon sebesar 5,130. Sedangkan untuk produk kemasan blangkon pada atribut motif kemasan sebesar 5,349, warna kemasan sebesar 4,356, kenyamanan penggunaan kemasan sebesar 4,329, logo sebesar 4,987, informasi pada kemasan sebesar 4,050 , bentuk kemasan sebesar 4,828, dan bahan kemasan sebesar 4,762. 
Tabel 1. Hasil Importance Rating Blangkon

\begin{tabular}{c|c|c|c}
\hline No & Kebutuhan Konsumen & Importance Rating & Urutan \\
\hline 1 & Kenyamanan Blangkon & 4.61 & 1 \\
2 & Awet & 4.57 & 2 \\
3 & Size Blangkon & 4.25 & 3 \\
4 & Warna Blangkon & 4.17 & 4 \\
5 & Motif Blangkon & 4.17 & 5 \\
6 & Model Blangkon & 4.09 & 6 \\
7 & Harga & 4.05 & 7 \\
8 & Bahan Eklusif & 3.87 & 8 \\
\hline
\end{tabular}

Tabel 2. Hasil Importance Rating Kemasan Blangkon

\begin{tabular}{c|c|c|c}
\hline No & Kebutuhan Konsumen & Importance Rating & Urutan \\
\hline 1 & Motif Kemasan & 4.26 & 1 \\
2 & Warna Kemasan & 4.22 & 2 \\
3 & Kenyamanan & 4.15 & 3 \\
4 & Penggunaan & 3.97 & 4 \\
5 & Logo & 3.91 & 5 \\
6 & Informasi pada & 3.83 & 6 \\
7 & Kemasan & 3.82 & 7 \\
\hline
\end{tabular}

Tabel 3. Technical Requirements Blangkon

\begin{tabular}{c|c}
\hline Technical Requirements & Target \\
\hline Kualitas bahan & Kain mori yang paling halus dan dapat dilipat \\
Mempunyai skala ukuran kepala & $50-62$ \\
Pemilihan warna & Warna emas atau gold \\
Tahan lama & $>10$ tahun \\
Kebersihan & Kain baru dan sudah dicuci \\
Desain ukuran & Adanya label ukuran untuk tiap blangkon \\
Murah & Sesuai harga produksi \\
Desain bentuk & Kombinasi tradisional dan moderen \\
\hline
\end{tabular}

Tabel 4. Technical Requirements Kemasan Blangkon

\begin{tabular}{c|c}
\hline Technical Requirements & Target \\
\hline Kualitas bahan & Karton tipis \\
Berat kemasan & 65 gram \\
Unik & Gambar blangkon dan merek \\
Pemilihan warna & Warna netral \\
Pemilihan motif & Batik \\
Siap digunakan & Mempunyai tali agar mudah digunakan \\
Praktis & Menggunakan 1 pintu masuk \\
Kelengkapan informasi & Logo, kontak penjual, size, filosofi blangkon \\
Desain tatanan informasi & Penataan yang menarik \\
\hline
\end{tabular}




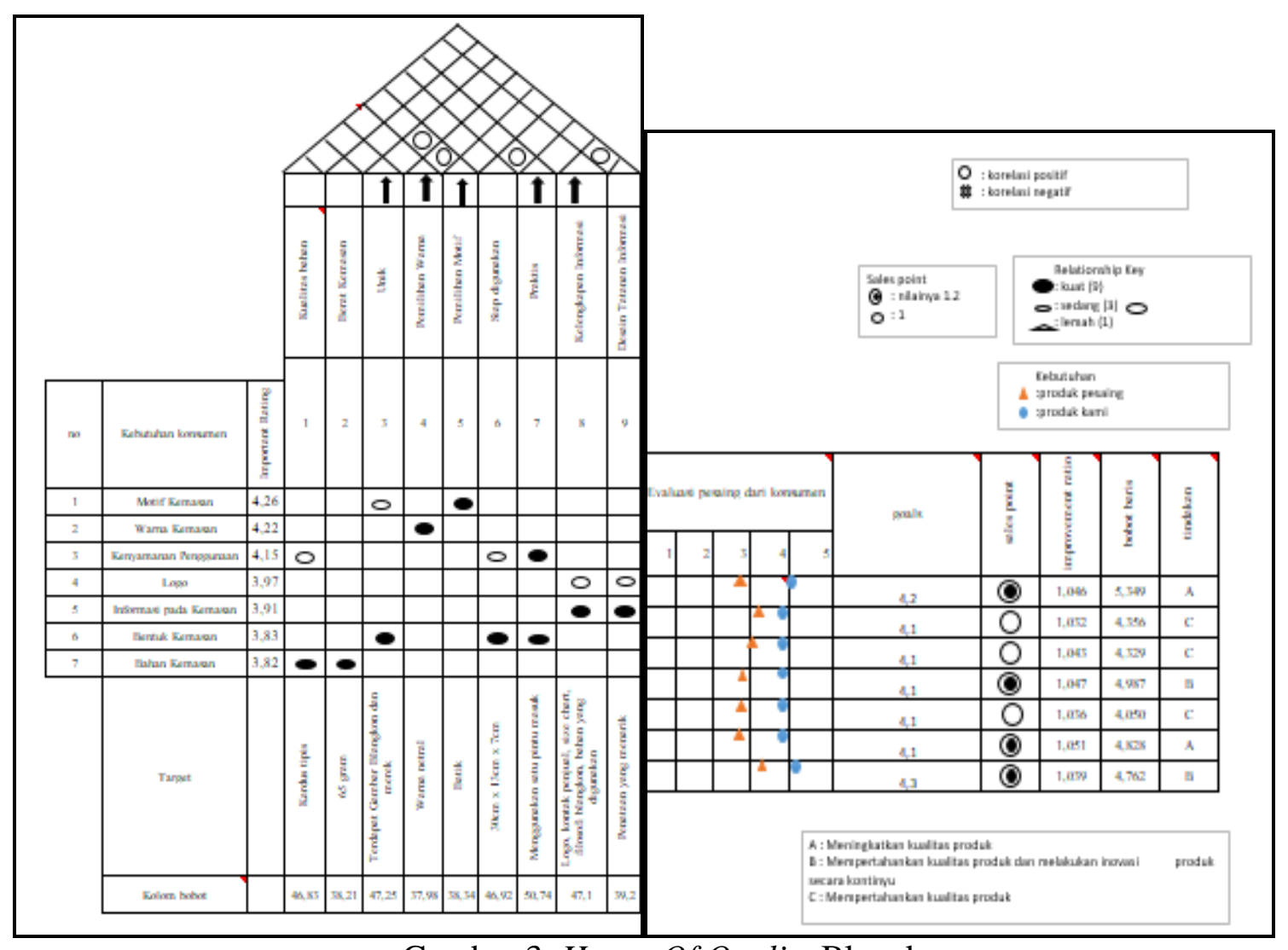

Gambar 3. House Of Quality Blangkon.

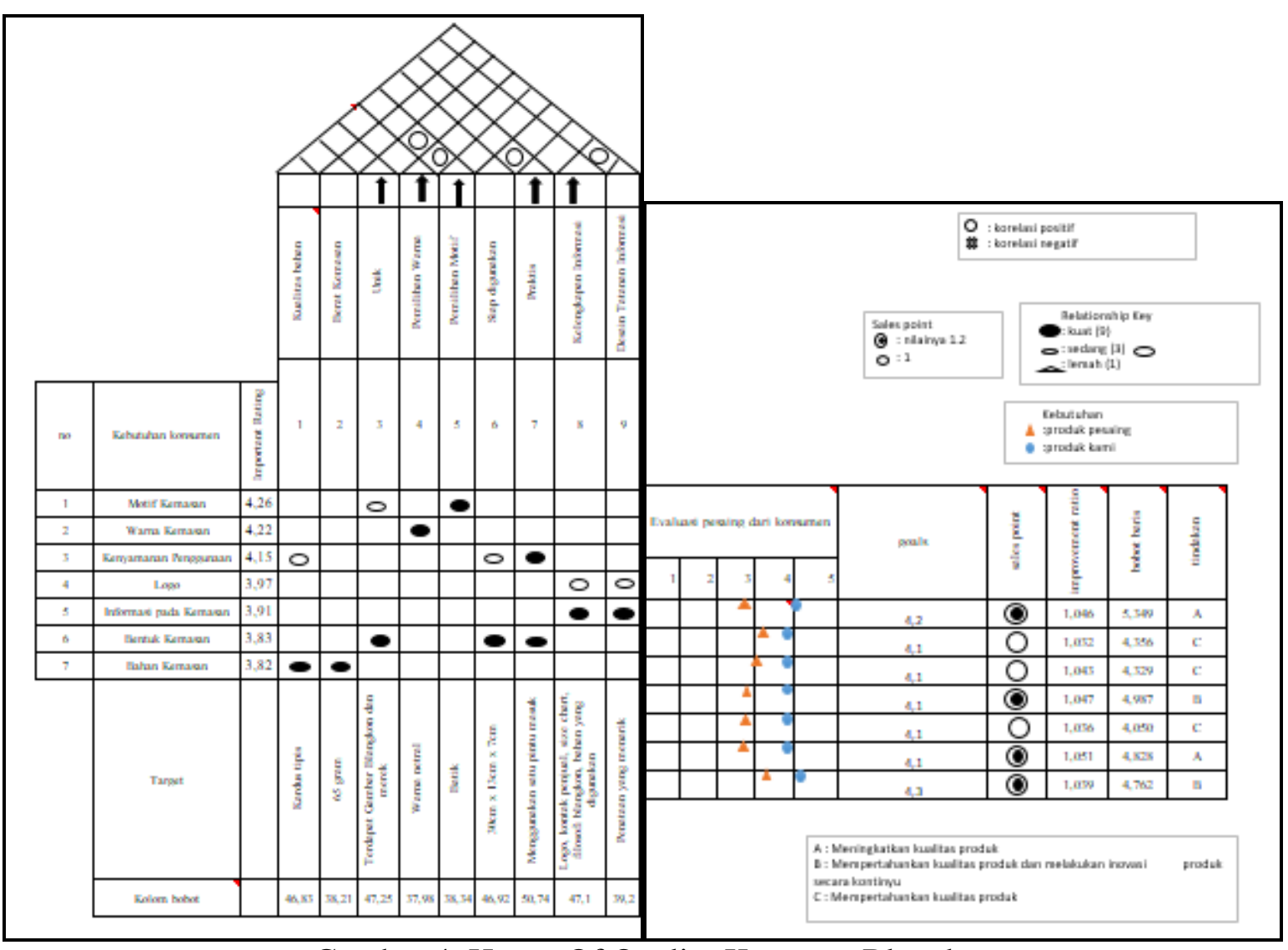

Gambar 4. House Of Quality Kemasan Blangkon. 


\section{KESIMPULAN}

Karakteristik yang didapat untuk produk blangkon yaitu kenyamanan blangkon, awet, size blangkon, warna blangkon, motif blangkon, model blangkon, harga, dan bahan eksklusif yang mempunya delapan karateristik teknis yaitu kualitas bahan, mempunyai skala ukuran kepala, pemilihan warna, tahan lama, desain ukuran, pemilihan motif, murah, dan desain bentuk.

Sedangkan untuk kemasan blangkon terdapat 7 karakteristik yaitu motif kemasan, warna kemasan, kenyamanan penggunaan, logo, informasi pada kemasan, bentuk kemasan, dan bahan kemasan yang memiliki sembilan karakteristik teknis yaitu kualitas bahan, berat kemasan, unik, pemilihan warna, pemilihan motif, siap digunakan, praktis, kelengkapan informasi dan desain tatanan informasi.

Usulan yang diberikan oleh peneliti untuk produk blangkon yaitu untuk menambah ragam warna untuk blangkon itu sendiri, desain yang diberikan mengikuti jaman namun tidak meninggalkan nilai nilai tradisional pada produk blangkon itu sendiri. Sedangkan untuk produk kemasan blangkon yaitu memberikan logo dan kemasan yang praktis serta unik untuk memberikan kesan yang lebih menarik

\section{DAFTAR PUSTAKA}

Anis, Muchlison., Azizah, Hidayati., Kontribusi Industri Kreatif Blangkon Pada Ekonomi Masyarakat. Seminar Nasional INACO., 2016.

Aryani, Dwi., Rosinta, Febrina., Pengaruh Kualitas Layanan terhadap Kepuasan Pelanggan dalam Membentuk Loyalitas Pelanggan. Bisnis \& Birokrasi, Jurnal Ilmu Administrasi dan Organisasi, MeiAgus 2010, hlm. 114-126., 2010.
E, Ristya Widi., Uji Validitas dan Uji Reliabilitas dalam Penelitian Epidemiologi Kedokteran Gigi. Stomatognatic (J.K.G. Unej) Vol. 8 No. 12011 : 27-34., 2011.

Efendi, Zulman., Penerapan Quality Fucntion Deployment (QFD) untuk Meningkatkan Kinerja Industri Kecil Bakso Sapi Berdasarkan Kepuasan Pelanggan. Jurnal Sain Peternakan Indonesia Vol. 2, No 2, Juli - Desember 2007.

Jono., Implementasi Metode Quality Fucntion Deployment (QFD) Guna Meningkatkan Kualitas Kain Batik Tulis. Jurnal Ilmiah Teknik Industri, Vol. 5, No. 1, Agst 2006, hal. 33 38., 2006.

Koestanto, Tri Hari., Pengaruh Kualitas Pelayanan Terhadap Kepuasan Pelanggan pada Bank Jatim Cabang Klampis Surabaya. Jurnal Ilmu \& Riset Manajemen Vol. 3 No. 10., 2014.

Ling, Ay.,. Pengelolaan dan Pengembangan Usaha Pada Usaha Mikro Kecil Menengah. Agora Vol. 1 No.1, 2013

Mahmud., Alfianto, Eko Agus., Pengaruh Desain Produk dan Layanan Purna Jual Terhadap Keputusan Konsumen Membeli Sepeda Motor Yamahan Merek New V-ixion FI (Full Injection). Jurnal Sketsa Bisnis Vol.1 Agustus 2014.

Panjaitan, Januar Efendi., Yuliati, Ai Lili., Pengaruh Kualitas Pelayanan Terhadap Kepuasan Pelanggan Pada JNE Cabang Bandung. DeReMa Jurnal Manajemen Vol. 11 No. 2, September 2016.

R, Sudjadi Tjipto., Pramusita, Rossa Dyana., Tinjauan Tampilan Visual Desain Kemasan Roti Murni di Yogyakarta. Andhapura, Vol. 2 No.2., 2016. 
Suhendar, Endang., Suroto., Penerapan Metode Quality Fucntion Deployment (QFD) Dalam Upaya Peningkatan Kualitas Pelayanan Akademik Pada UB. Faktor Exacta 7(4): 372-386, 2014.

Sukarno, Gendut., Meningkatkan Kinerja Pemasaran UMKM Melalui Peran Lingkungan, Inovasi Produk dan Kreatifitas Strategi Pemasaran. Ekuitas, Vol. 15 No 3., 2011.

Susanto, Agus., Indra, Akmal., Yuliandra, Berry., Pengembangan Desain Produk dengan Metode QFD: Studi Kasus Desain Peralatan Pembuat Adonan Roti untuk Usaha Skala Kecil. Proceeding Seminar Nasional Tahunan Teknik Mesin XIV (SNTTM XIV)., 2015.

Syaputri, Ria., Pengaruh Kemasan, Merek dan Harga Terhadap Loyalitas Konsumen Pada UKM Keripik Singkong Sulis di Samarinda. EJurnal Ilmu Administrasi Bisnis, Vol. 3 No.1 2015: 27-39., 2015.

Wahyono, Tri., Perajin Blangkon Yang Tak Lagi Diminati. Jantra Vol. IV, No. 8 Hal 697-706., 2009. 